\title{
Eremopyrum (Ledeb.) Jaub. \& Spach, a new genus for the flora of western Europe (Iberian Peninsula)
}

\author{
Miguel Cueto ${ }^{1 *}$, Julián Fuentes ${ }^{2}$ \& Gabriel Blanca ${ }^{3}$ \\ 'Departamento de Biología y Geología, CECOUAL, Universidad de Almería, ES-04120 Almería, Spain. \\ ${ }^{2} \mathrm{C} /$ Castillo 5, bajo F, ES-18140 La Zubia, Granada, Spain. \\ ${ }^{3}$ Departamento de Botánica, Facultad de Ciencias, Universidad de Granada, C/ Fuentenueva s/n, ES-18001 Granada, \\ Spain.
}

\section{Correspondencia}

M. Cueto

e-mail: mcueto@ual.es

Recibido: 25 diciembre 2017

Aceptado: 9 mayo 2018

Publicado on-line: junio 2018
Eremopyrum (Ledeb.) Jaub. \& Spach, un nuevo género para la flora de Europa occidental (Península Ibérica)

Key words: Flora, Europa, Poaceae, Eremopyrum.

Palabras clave: Flora, Europa, Poaceae, Eremopyrum.
Eremopyrum (Ledeb.) Jaub. \& Spach was first recognized as a taxon by Ledebour (1829), who treated it as Triticum sect. Eremopyrum. Bentham \& Hooker (1883) transferred it to Agropyron Gaertn., leaving it as a section (Cabi \& Dogan, 2010). Jaubert \& Spach (1851) recognized Eremopyrum as a genus, distinguishing it from Agropyron on the basis of its annual habit [Type: Eremopyrum orientale (L.) Jaub. \& Spach, lectotype selected by Nevski (1936)]. It is a well-circumscribed genus with an annual habit and oblong to orbicular fragile spike-like inflorescence that is used in wheat improvement (Clayton \& Renvoize, 1986). The chromosomes of Agropyrum, as usually found within the Triticeae, are meta- or submetacentric (Schulz-Schaeffer \& Jurasits, 1962), whereas the chromosomes of Eremopyrum are predominantly telo- or subtelocentric (Frederiksen, 1991).

To date, 18 species and many infraspecific taxa have been described, but the number of species accepted varies from four (Tzvelev, 1976; Sakamoto, 1979; Frederiksen, 1991) to nine (Löve, 1984). The Plant List (2013) currently recognizes four species and 44 synonyms: $E$. buonapartis (Spreng.) Nevski, E. distans (K. Koch) Nevski, E. orientale (L.) Jaub. \& Spach, and E. triticeum (Gaertn.) Nevski. In the Mediterranean region, Valdés \& Scholz (2009) cite the four aforementioned species and furthermore E. confusum Melderis, with an Algerian distribution.

Jaubert \& Spach (1851) cited E. orientale and E. squarrosum Jaub. \& Spach (= E. buonapartis) in "Iberia", probably the Caucasus, not the Iberian Peninsula. Melderis (1980) and The Plant List (2013) indicates the presence, at the European level, of only $E$. distans in eastern Europe and $E$. orientale and $E$. triticeum in south-eastern and eastern Europe. Melderis (1980), Blanca et al. (2011), Ibn Tattou (2014) and The information system of the plants of Spain (Anthos, 2017) contains no indication of the presence of this genus in the Iberian Peninsula.

During the course of the plant collection by the authors in 2017 and 2018 in the Guadix Depression (Granada, Spain) a population of $E$. orientale (Fig. 1) was located, consisting of several thousand individuals growing on expansive clays attributed to a Triassic Keuper facies (Marchal et al., 2011), accompanied by Astragalus guttatus Banks \& Solander, Daucus aureus Desf., Rochelia disperma (L. fil.) C. Koch subsp. disperma, Plantago coronopus L., Echinaria capitata (L.) Desf., Cleonia Iusitanica (L.) L., Moricandia moricandioides subsp.

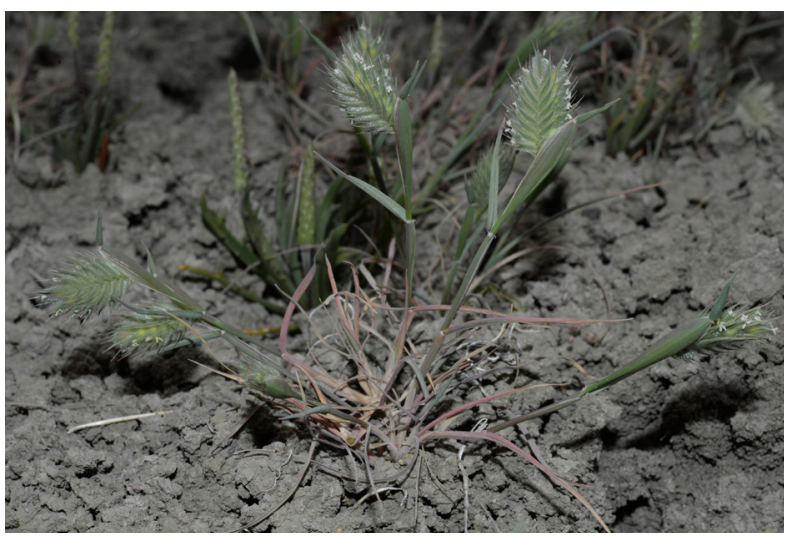

Figure 1. Eremopyrum orientale (L.) Jaub. \& Spach. Spain. Granada: Pedro Martínez. G. Blanca personal collection of photographs.

Figura 1. Eremopyrum orientale (L.) Jaub. \& Spach. Spain. Granada: Pedro Martínez. Foto G. Blanca. 


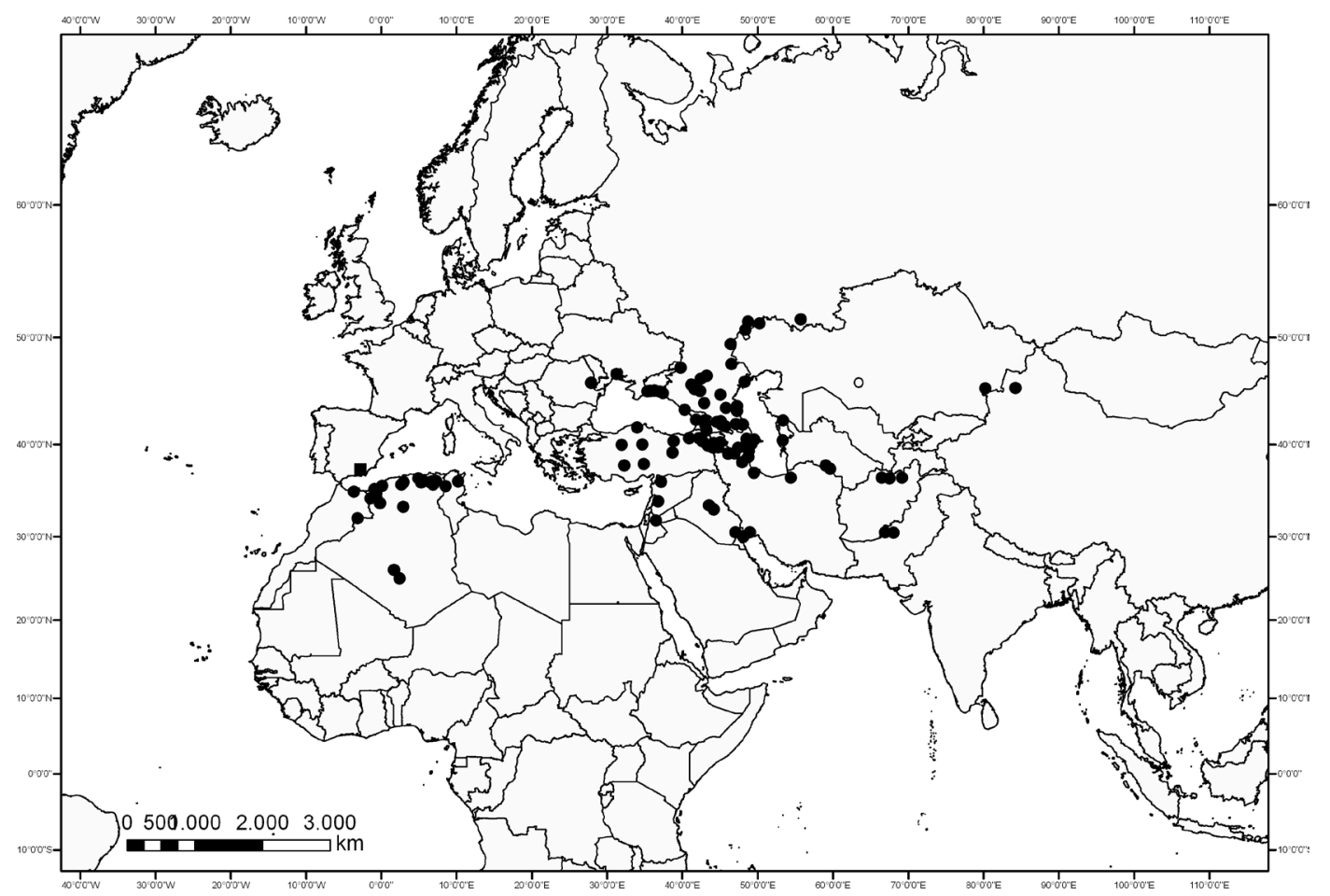

Figure 2. Known distribution of Eremopyrum orientale (L.) Jaub. \& Spach (based in Frederiksen, 1991; Cabi \& Dogan,

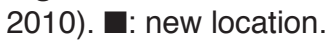

Figura 2. Distribución conocida de Eremopyrum orientale (L.) Jaub. \& Spach (basada en Frederiksen, 1991; Cabi \& Dogan, 2010). $\mathbf{~ : ~ n u e v a ~ l o c a l i d a d . ~}$

baetica (Boiss. \& Reut.) Sobrino Vesperinas, Sedum sediforme (Jacq.) Pau, Coronilla scorpioides (L.) W. D. J. Koch, Echinops strigosus L., and dispersed individuals of Camphorosma monspeliaca L. subsp. monspeliaca, forming part of communities of sub-steppe areas of grasses and annuals of Thero-Brachypodietea included in Habitat 6220 (considered a priority) of the European Habitat Directive (Doue, 2013). It is considered to be native taxon, not from reverting to the wild, since it is found in a territory where no human activity at all is appreciated. The reasons for its having gone unnoticed until now are primarily that it is very isolated, far from localities of botanical interest, and probably submitted to pronounced population fluctuations that support taxa that inhabit these semiarid terrains due to the irregular annual and interannual regimes of precipitation.

Sheets in the Herbaria GDA and HUAL were included. Fig. 2 shows the distribution known from the works of Frederiksen (1991) and Cabi \& Dogan (2010) and the new locality. According to the IUCN (2012) categories and recommendations provided by IUCN (2017), we suggest labelling the Iberian population of $E$. orientale as endangered (EN), with the following criteria: A4ac; B1ac(i,ii,iii,iv)+2ac(i,ii,ii i,iv).
Eremopyrum orientale (L.) Jaub. \& Spach, III. PI. Orient. 4: 26 (1851)

Secale orientale L., Sp. Pl.: 84 (1753) (basionym)

Triticum orientale (L.) M. Bieb., Fl. Taur.-Caucas. 1: 86 (1808)

Agropyron orientale (L.) Roem. \& Schult., Syst. Veg., 2: 757 (1817)

Costia orientalis (L.) Willk., Bot. Zeitung (Berlin) 16: 377 (1858)

Annual, caespitose, (6-)9-25(-30) cm long, densely and shortly hirsute in the lower half. Leaf-sheath somewhat inflated on the upper half, glabrous inside; auricles falcate. Ligule c. $1 \mathrm{~mm}$, membranaceous, denticulate. Leaf blade 15-70 × 1-2 mm, acute, with prominent venation, scaberulous to shortly hirsute adaxially and abaxially; margins scabrous. Inflorescence a solitary and terminal spike, $13-30 \times 10-15 \mathrm{~mm}$, oblong or ovate, bilateral, dense, subtended by an \pm inflated leaf-sheath; peduncle pubescent. Rachis fragile at the nodes, disarticulating above each spikelet; internodes oblong; rachilla tough. Spikelets crowded, sessile, somewhat canaliculate, with 2 fertile florets and 1 sterile, falling entire. Glumes 6-9 mm long including awn, similar, arranged laterally to all sides, shorter 
than lemmas, lanceolate, strongly incurved and subulate-awned on the upper half, assymetrically keeled, 3-5-veined, coriaceous, densely covered by long white hairs and with scabrid veins. Lemma 7-10 mm long including awn, lanceolate, acuminate, strongly keeled above, 5-veined, coriaceous, densely covered by long white hairs and with scabrid veins; awn (0.5-)1-2 mm. Palea shorter than body of lemma, lanceolate, acute, with 2 submarginal prominent veins, 2-fid, glabrous to slightly scabridulous in the veins. Lodicules 2 , ciliate. Anthers 1.6-1.9 mm long. Caryopsis c. 2.5 $\mathrm{mm}$, ellipsoidal.

Distribution: South-eastern and eastern Europe and south-eastern Iberian Peninsula, North Africa, temperate and tropical Asia.

Material studied: Spain. Granada: Pedro Martínez, Hoya de Guadix, Rambla del Carril, 30SVG8346, pastizales terofíticos en colinas de margas arcillosas, 830 m, 24 April 2017, J. Fuentes \& G. Blanca (GDA 62698; HUAL 26073); Fonelas, hacia El Mencal, terrenos arcillosos, 1 April 2017, J. Fuentes \& G. Blanca (GDA 62633); Fonelas, entre Cortijo de Victoriano y Cortijo Nuevo, 30SVG8748, arcillas expansivas, $780 \mathrm{~m}, 31$ April 2018, J. Fuentes, G. Blanca \& J.M. Segura (GDA 62721); Fonelas, entre Majada del Cura y Cerro de los Pedernales, 30SVG8648, arcillas expansivas, $780 \mathrm{~m}, 31$ April 2018, J. Fuentes, G. Blanca \& J.M. Segura (GDA 62718); Fonelas, Cerro del Abad, 30SVG8747, arcillas expansivas, 760 m, 31 April 2018, J. Fuentes, G. Blanca \& J.M. Segura (GDA 62720); Fonelas, Cabecera del Barranco de la Linde, 30SVG8747, arcillas expansivas, 770 m, 31 April 2018, J. Fuentes, G. Blanca \& J.M. Segura (GDA 62719); Fonelas, proximidades del Cortijo de Victoriano, 30SVG8748, arcillas expansivas, 730 m, 11 May 2018, M. Cueto \& G. Blanca (HUAL 26156, 26157).

\section{References}

Anthos (2017). Sistema de información de las plantas de España. Real Jardín Botánico, CSIC-Fundación Biodiversidad. Published on the Internet. www.anthos. es [accessed 2 May 2017]

Bentham, G. \& Hooker, J. D. (1883). Genera Plantarum 3. London: Williams \& Norgate.

Blanca, G., Cabezudo, B., Cueto, M., Salazar, C. \& Morales Torres, C. (Eds.) (2011). Flora Vascular de Andalucía Oriental, 2nd edition. Universidades de Almería, Granada, Jaén y Málaga, Granada, 1751 pp.

Cabi, E. \& Dogan, M. (2010). Taxonomic study on the genus Eremopyrum (Ledeb.) Jaub. et Spach (Poaceae) in Turkey. Plant Systematics and Evolution 287, 129-140. https://doi.org/10.1007/s00606-0100306-1

Clayton, W. D. \& Renvoize, S. A. (1986). Genera Gramineum. Grasses of the World. Kew Bulletin Additional Series 13, 1-389

Doue (2013). Directiva 2013/17/UE del Consejo de 13 de mayo de 2013 por la que se adaptan determinadas directivas en el ámbito del medio ambiente, con motivo de la adhesión de la República de Croacia. Diario Oficial de la Unión Europea, 560, 193-229

Frederiksen, S. (1991). Taxonomic studies in Eremopyrum (Poaceae). Nordic Journal of Botany 11, 271-285.

Ibn Tattou, M. (2014). 989. Eremopyrum (Ledeb.) Jaub. \& Spach. In M. Fennane, M. Ibn Tattou \& J. El Oualidi, Flore Practique du Maroc vol. 3 (pp. 626-627). Rabat: Cana Print.

IUCN (2012). IUCN Red List Categories and Criteria: Version 3.1. IUCN Species Survival Commission, Gland, Switzerland and Cambridge, UK.

IUCN (2017) Guidelines for Using the IUCN Red List Categories and Criteria: Version 13. Standards and Petitions Subcomitee. Gland, Switzerland and Cambridge, UK.

Jaubert, C. \& Spach, E. (1851). Gramineae Orientales Novae vel Criticae. Annales des Sciences Naturelles. Troisième Série. Botanique. Tome Quatorzieme, 351366.

Ledebour, C. F. (1829). Flora Altaica. Tomus I (Classis I-V), 113.

Löve, A (1984). Conspectus of the Triticeae. Feddes Repertorium 95, 425-521.

Marchal, F. M., Lendínez, M. L., García Fuentes, A. \& Torres, J. A. (2011). Yesos del Guadiana Menor. In J. F. Mota, P. Sánchez-Gómez \& J. S. Guirado (Eds.), Diversidad vegetal de las yeseras ibéricas. El reto de los archipiélagos edáficos para la biología de la conservación (pp. 481-484). Almería, España: ADIFMediterráneo Asesores Consultores.

Melderis, A. (1980). 50. Eremopyrum (Ledeb.) Jaub. \& Spach. In T. G. Tutin, V. H. Heywood, N. A. Burges, D. M. Moore, D. H. Valentine, S. M. Walters \& D. A. Webb (Eds.), Flora Europaea V. (pp. 200). Cambridge: Cambridge University Press.

Nevsky, S. A. (1936). Conspectus Loliearum, Nardearum, Lepturearum. Hordeearunquem Florae Unionis Rerum Publicarum Sovieticarum Socialisticarum. Trudy Botani Eeskogo instituta Akademii nauk SSSR. Ser. I. Flora i sistematika vyssih rastenij 2: 33-90.

Sakamoto, S. (1979). Genetic relationships among four species of the genus Eremopyrum in the tribe Triticeae, Gramineae. Memoirs of the College of Agriculture, Kyoto University 114, 1-27.

Schulz-Schaeffer, J. \& Jurasits, P. (1962). Biosystematic investigation in the genus Agropyrum. I. Cytological studies of species karyotypes. American Journal of Botany 49, 940-953.

The Plant List (2013). Version 1.1. Published on the Internet; http://www.theplantlist.org/2 (accessed 5 May 2017).

Tournefort, J. P. (1703). Corollarium institutionum rei herbariae, in quo plantae 1356 munificentia Ludovici Magni in Orientalibus regionibus observatae recensentur. París: Typographia Regia.

Tzvelev, N. N. (1976). Tribe 3. Triticeae Dumort. Poaceae URSS. Leningrad: Academia Scientiarum URSS.

Valdés, B. \& Scholz, H.; with contributions from RaabStraube, E. von \& Parolly, G. (2009). Poaceae (pro parte majore). Euro+Med Plantbase. 